\title{
Evidence of Two Formae Speciales in Venturia inaequalis, Responsible for Apple and Pyracantha Scab
}

\author{
Bruno Le Cam, Luciana Parisi, and Laurence Arene
}

First and second author: UMR de Pathologie Végétale; and third author: Unité d'Amélioration des Plantes, Institut National de la Recherche Agronomique, B.P. 57. 42, rue Georges Morel, 49071 BEAUCOUZE Cedex, France. Accepted for publication 5 November 2001.

\begin{abstract}
Le Cam, B., Parisi, L., and Arene, L. 2002. Evidence of two formae speciales in Venturia inaequalis, responsible for apple and Pyracantha scab. Phytopathology 92:314-320.

Genetic relationships, mating crosses, and host specificity of Venturia inaequalis isolates from Malus spp. and of Spilocaea pyracanthae isolates from Pyracantha spp. were evaluated. Sequence analysis of the complete internal transcribed spacer (ITS) region (ITS1-5.8S to ITS2) revealed a total similarity between these two putative species. ITS restriction fragment length polymorphism carried out with five restriction enzymes on a collection of 28 isolates confirmed a lack of diversity in

were divided into two distinct monophyletic groups in a phylogenetic tree using ITS sequence comparison. These groups were related to their anamorph (i.e., Spilocaea or Fusicladium). When inoculated on their host of origin, fields isolates caused typical symptoms of scab disease, and a host specificity was demonstrated by cross pathogenicity of isolates from Malus $\times$ domestica and Pyracantha spp. Mating on dried leaves in vitro between one isolate of each putative species led to production of numerous perithecia. Ninety-six sporulating monoascosporic progenies were isolated from this cross. Based on these genetic and pathogenic data, we proposed that pathogens responsible for scab on Malus spp. and Pyracantha spp. are considered as two formae speciales belonging to $V$. inaequalis.
\end{abstract} this region between and within these two populations. Additional isolates from three related species (V. pirina, V. nashicola, and S. eriobotryae)

The ascomycete Venturia inaequalis (Cooke) G. Wint. is responsible for the most important disease of apple in temperate countries. Pathogenic behavior of this fungus is now well described. Seven races were identified and genetic studies have demonstrated that the relationships between $V$. inaequalis and Malus spp. fit the gene-for-gene theory (2). V. inaequalis is a heterothallic fungus with a sexual cycle occurring each year in winter, followed by many asexual reproduction cycles during the epidemic phase. This mixed reproduction system is conducive to a high genetic diversity within populations (28) and is supposed to be a factor facilitating adaptation of pathogens to specific resistance genes of the host both by increasing risks of avirulence losses and spreading of new virulences. The $V m$ resistance gene, introgressed from Malus micromalus in cultivated apples, has been rapidly overcome by race 5 while it was introduced in only six cultivars (31). Improved cultivars released by plant breeding programs carry the $V f$ gene from $M$. floribunda 821 , first considered as conferring durable resistance (8). Although this gene has, to date, scarcely been used in commercial plantations, resistance breakdown has already occurred in many countries $(19,20,22)$, demonstrating that the durability of resistance introduced in such a perennial crop remains questionable because of the capability of $V$. inaequalis to overcome resistance under monogenic determinism.

Within the genus Venturia (anamorphs Fusicladium, Spilocaea, and Cladosporium), 52 species have been described (26). Most are pathogens of fruit trees or ornamental plants. The host plant pyracantha, Pyracantha sp. Roem., is particularly susceptible to scab. A breeding program on this plant was developed in the United States by Egolf in 1970 (10); it was aimed at scab resistance as well as at evergreen or fructification criteria. The associ-

Corresponding author: B. Le Cam; E-mail address: lecam@angers.inra.fr

Publication no. P-2001-1228-01R

(c) 2002 The American Phytopathological Society
Additional keywords: cross inoculations, host specificity. ated anamorph of pathogens responsible for scab on Malus $\times$ domestica and on Pyracantha spp. belong to the genus Spilocaea. The sexual form has never been reported for the pathogen of this shrub. Therefore, it is called Spilocaea pyracanthae (G. Otth) Arx. Distinction between $V$. inaequalis and $S$. pyracanthae based on morphological criteria and on cross pathogenicity remains controversial (26). Moreover, no comparative genetic studies have been reported, and current data fails to discriminate these two putative species. Defining the limits of these species is of great interest in order to evaluate diversity of the pathogen and predict the potential spread of genes involved in pathogenicity. Pyracanthas are commonly planted in gardens and hedges, and wind distribution may contribute to migration of the fungus in orchards (28). The host range of these two pathogens is not yet clearly defined; therefore, the role of pyracantha as an alternative host of $V$. inaequalis acting as source of diversity remains to be evaluated.

In most eukaryotic organisms, ribosomal DNA (rDNA) comprises a multigene family with copies arranged in tandem repeats. Many analyses of DNA sequences dealing with fungi have been based on the rDNA repeat because of their conserved molecular function (25), and they are commonly used for taxonomic studies. Recently, characterization of rDNA has been employed to explain phylogenetic relationships within species of the genus Venturia that cause scab on tree fruit crops (24). Their findings, based on internal transcribed spacer (ITS) region ITS1-5.8S to ITS2 sequences, were that $V$. inaequalis differed from other species isolated from Pyrus spp. or Prunus spp.

To elucidate the relationships between $V$. inaequalis and $S$. pyracanthae, we first carried out an analysis of variation within ITS sequences of isolates representative of these two groups and from related species. Digestions of amplified ITS of a larger number of isolates (28) with five restriction enzymes were further carried out to confirm the results. In a second step, we prepared crosses in vitro between $S$. pyracanthae (isolate 186) and two isolates of $V$. inaequalis with opposite mating type (isolates 104 and 302) in 
order to test the hypothesis of a single species. Host range of these two putative species was then tested by cross-inoculations of Pyracantha spp. cuttings and Malus $\times$ domestica seedlings with $V$. inaequalis and $S$. pyracanthae.

\section{MATERIALS AND METHODS}

Polymorphism in rDNA region. Fungal isolates. Characteristics and origin of Venturia sp. and Spilocaea sp. strains used in this study are listed in Table 1 . Strains used were isolated from apple (Malus $\times$ domestica), firethorn (Pyracantha $\mathrm{sp}$.), European pear (Pyrus communis), Japanese pear (P. pyrifolia var. culta), and loquat (Eriobotrya japonica). They were derived from monoconidial isolates. Fungal cultures were stored on malt agar (Merck, Darmstadt, Germany) at $4^{\circ} \mathrm{C}$.

Mycelial growth and DNA extraction. Each isolate initially was grown on malt agar (Merck) plates for at least 20 days at $17^{\circ} \mathrm{C}$. Plugs of mycelium were deposited on the surface of a malt agar plate covered up by a sheet of cellophane. After 7 days of incubation, $10 \mathrm{mg}$ of agarless mycelium was gently scrapped from the surface and placed in a $1.5-\mathrm{ml}$ microcentrifuge tube containing $100 \mu \mathrm{l}$ of lysis buffer (50 mM Tris- $\mathrm{HCl}, \mathrm{pH} 7.2,50 \mathrm{mM}$ EDTA, $3 \%$ sodium dodecyl sulfate, $1 \% 2$-mercaptoethanol). DNA extraction was then performed as previously described $(12,16)$. Concen- tration of DNA was determined using UV spectrophotometry; the final concentration was adjusted with distilled water to $10 \mathrm{ng} / \mu \mathrm{l}$ and stored at $-20^{\circ} \mathrm{C}$.

Polymerase chain reaction amplification and digestion. Amplification of the ITS was performed in a programmable thermocycler (GeneAmp PCR System 9700; Applied Biosystems, Inc., Foster City, CA). The primer sequences used were 5'-TCCGTAGGTGAACCTGCGG-3' (ITS1) from the 18S, and $5^{\prime}$-TCCTCCGCTTATTGATATGC-3' (ITS4) from the 28S rDNA (30). A 50- $\mu 1$ reaction mixture contained $0.8 \mu \mathrm{M}$ each primer, $200 \mu \mathrm{M} \mathrm{dNTP}$, 1 unit of red Gold Star polymerase (Eurogentec SA, Herstal, Belgium), $1 \times$ amplification buffer (75 mM Tris- $\mathrm{HCl}, \mathrm{pH} 9), 20 \mathrm{mM}$ $\left(\mathrm{NH}_{4}\right)_{2} \mathrm{SO}_{4}, 0.01 \%$ (wt/vol) Tween $20,5 \mathrm{mM} \mathrm{MgCl}$, and $30 \mathrm{ng}$ of template DNA. The mixture was subjected to an initial denaturation for $5 \mathrm{~min}$ at $94^{\circ} \mathrm{C}$, followed by 30 cycles of denaturation at $94^{\circ} \mathrm{C}$ for $30 \mathrm{~s}$, annealing at $60^{\circ} \mathrm{C}$ for $30 \mathrm{~s}$, a 45 -s extension at $72^{\circ} \mathrm{C}$, and $7 \mathrm{~min}$ of final extension at $72^{\circ} \mathrm{C}$. Polymerase chain reaction (PCR) amplification was analyzed by electrophoresis through $1.4 \%$ agarose gel in a $0.5 \times$ Tris-Borate-EDTA buffer, stained with ethidium bromide and visualized under UV light $(300 \mathrm{~nm})$. Digestions with restriction enzymes were performed in a final volume of $20 \mu \mathrm{l}$ with 12 or $15 \mu \mathrm{l}$ of PCR products and eight units of the following enzymes: TaqI, EcoRI, MspI, Tsp509I (Eurogentec), and RsaI (New England Biolabs Inc., Beverly, MA). Reactions were

TABLE 1. Fungal strains used in this study ${ }^{\mathrm{a}}$

\begin{tabular}{|c|c|c|}
\hline Fungal strains & Isolation (country and date) & Host plant \\
\hline \multicolumn{3}{|c|}{ Venturia inaequalis } \\
\hline 93 race 1 & URSS - 1974 & Malus $\times$ domestica 'McIntosh' \\
\hline 104 race $1^{b}$ & St. Lézin, France - 1978 & Malus $\times$ domestica 'Golden Delicious' \\
\hline 119 race 1 & Romania - 1980 & Malus $\times$ domestica 'Golden Delicious' \\
\hline 1105 race 1 & The Netherlands - 1994 & Malus $\times$ domestica 'Golden Delicious' \\
\hline 330 race 2 & Germany - 1988 & Malus $\times$ domestica \\
\hline 855 race 3 & Germany -1991 & Malus $\times$ domestica \\
\hline 856 race 3 & Germany - 1991 & Malus $\times$ domestica \\
\hline 405 race 4 & Bordeaux, France - 1988 & Malus $\times$ domestica \\
\hline 740 race 4 & Beaucouzé, France - 1991 & Malus $\times$ domestica \\
\hline 147 race 5 & Beaucouzé, France - 1985 & Malus $\times$ domestica \\
\hline 105 race 5 & New York, USA - 1979 & Malus $\times$ domestica \\
\hline 844 race 5 & Germany - 1991 & Malus $\times$ domestica \\
\hline 302 race $6^{\mathrm{b}, \mathrm{c}}$ & Ahrensburg, Germany - 1988 & Malus $\times$ domestica $81 / 11-22^{\mathrm{d}}$ \\
\hline 1060 race $7^{e}$ & Beaucouzé, France -1993 & Malus floribunda 821 \\
\hline 1144 race 7 & The Netherlands - 1994 & Malus floribunda \\
\hline 1066 race $7^{c, e}$ & Beaucouzé, France - 1993 & Malus floribunda 821 \\
\hline \multicolumn{3}{|c|}{ Spilocaea pyracanthae } \\
\hline D 38.2 & Beaucouzé, France - 1993 & Pyracantha koüdzumii $\times$ P. coccinea 'Mohave' \\
\hline D 38.5 & Beaucouzé, France - 1993 & P. koüdzumii $\times P$. coccinea 'Mohave' \\
\hline D 38.6 & Beaucouzé, France - 1993 & P. koïdzumii $\times P$. coccinea 'Mohave' \\
\hline D $38.7^{\mathrm{c}}$ & Beaucouzé, France - 1993 & P. koïdzumii $\times$ P. coccinea 'Mohave' \\
\hline D 38.8 & Beaucouzé, France - 1993 & P. koïdzumii $\times$ P. coccinea 'Mohave' \\
\hline D 38.9 & Beaucouzé, France - 1993 & P. koïdzumii $\times$ P. coccinea 'Mohave' \\
\hline D 19.3 & Beaucouzé, France - 1993 & P. coccinea 'Lalandei' \\
\hline $186^{\mathrm{b}, \mathrm{c}}$ & Ireland - 1987 & Pyracantha sp. \\
\hline 1381 & La Meignanne, France - 1998 & Pyracantha sp. \\
\hline 1383 & France - 1998 & Pyracantha sp. \\
\hline 1388 & France - 1998 & Pyracantha sp. \\
\hline $\mathrm{V} 55^{\mathrm{f}}$ & Dossenheim, Germany - 1995 & Pyracantha sp. \\
\hline \multicolumn{3}{|l|}{ Venturia pirina } \\
\hline $\mathrm{P} 11^{\mathrm{c}}$ & Beaucouzé, France - 1991 & Pyrus communis 'Président Drouart' \\
\hline $\mathrm{P} 64^{\mathrm{c}}$ & The Netherlands - 1995 & Pyrus communis 'Doyenne' \\
\hline \multicolumn{3}{|c|}{ Venturia nashicola } \\
\hline $\mathrm{P} 17^{\mathrm{c}}$ & Lanxade, France - 1991 & Pyrus pyrifolia 'Culta' \\
\hline $\mathrm{P} 63^{\mathrm{c}}$ & Bergerac France - 1996 & Pyrus pyrifolia 'Culta' \\
\hline \multicolumn{3}{|c|}{ Spilocaea eriobotryae } \\
\hline $1389^{\mathrm{c}, \mathrm{g}}$ & Montpellier, France - 1998 & Eriobotrya japonica \\
\hline
\end{tabular}

${ }^{a}$ Unless otherwise specified, the strains were from our laboratory.

b Strains tested for sexual crosses.

c Strains in which the complete internal transcribed spacer (ITS) region was sequenced and aligned.

d Progeny $(V f / v f)$ of a Prima $(V f / v f)$ x A143/24 ( $v f / v f)$ cross.

e Strains originating from the Fl 1 isolate described by Roberts and Crute (22).

f Strain V55 was supplied by A. Kollar, Institute for Plant Protection in Fruit Crops, Dossenheim, Germany.

g Strain 1389 was supplied by J. L. Notteghem, ENSA, Montpellier, France. 
carried out under conditions as recommended by the manufacturers. The digested DNA fragments were separated on $4.5 \%$ Nusieve GTG agarose gels (FMC BioProducts, Rockland) and visualized as described above. A 100-bp molecular weight ladder (Eurogentec) was used as size standard.

DNA sequencing. PCR products were purified using a Qiagen kit (Qiagen, Hilden, Germany) and then sequenced by using a Taq Dye Deoxy terminator sequencing kit and a model ABI 377 automatic sequencer (Applied Biosystems). Primers used were ITS1 and ITS4 as described above. Two isolates of each species were sequenced (V. inaequalis: strains 302 and 1066; S. pyracanthae: strains 186 and D38.7; V. pirina: strains P64 and P11; and $V$. nashicola: strains $\mathrm{P} 63$ and P17), except for $S$. eriobotryae (only one strain: 1389).

Sexual crossing. A strain of $S$. pyracanthae (186) was crossed with two strains of $V$. inaequalis of known mating type (13): strain $302(+)$ and strain $104(-)$. Crosses were carried out according to protocol as described (13). They were performed under sterile conditions on 56 air-dried foliar disks from M. domestica (cv. Gala) and from Pyracantha $\times(\mathrm{cv}$. Mohave). Disks were inoculated with mixed mycelia of the two strains and incubated for
21 days at $17^{\circ} \mathrm{C}$ in the darkness and then at $8^{\circ} \mathrm{C}$ for 140 days. Perithecia obtained were crushed and spread on water agar plates (Merck), and germinated ascospores were isolated individually under optical microscope after $48 \mathrm{~h}$ at $20^{\circ} \mathrm{C}$.

Cross pathogenicity tests. Fungal material and inoculum preparation. V. inaequalis and $S$. pyracanthae inoculum consisted of local populations collected in diverse apple orchards or nurseries of $P$. coccinea in the area of Angers, France. Initial conidial suspensions derived from scabbed leaves of apple and pyracantha or were obtained in Roux Flasks as previously described (15). These conidial suspensions were thereafter sprayed either on batches of apple or firethorn seedlings according to Parisi et al. (20). This first inoculation allowed numerous scabbed leaves to collect that were stored at $-20^{\circ} \mathrm{C}$. Leaves then were rinsed with distilled water: this new conidial suspension was adjusted to 250,000 conidia per $\mathrm{ml}$ and was used next for plant inoculation. Strains 186 (S. pyracanthae) and 302 (V. inaequalis) used in mating experiment also were tested independently for their pathogenicity on apple seedlings.

Plant material. Seedlings originating from two crosses of Malus $\times$ domestica ('Golden Delicious' $\times$ 'Idared' and 'Florina' $\times$

ITS1 $\rightarrow$

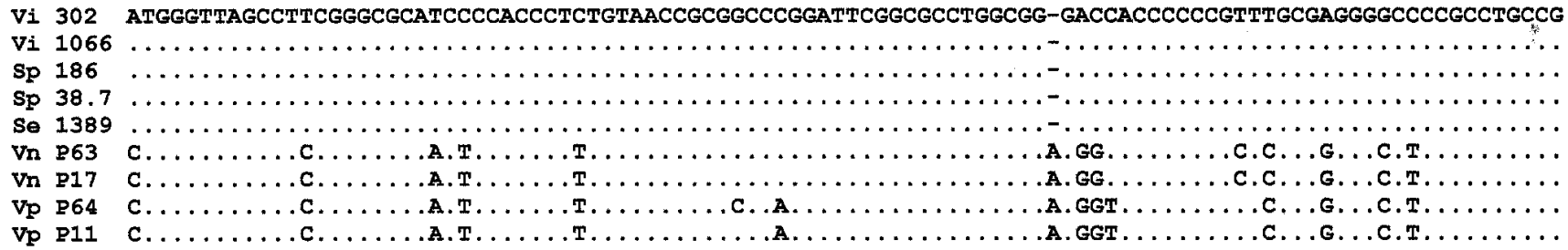

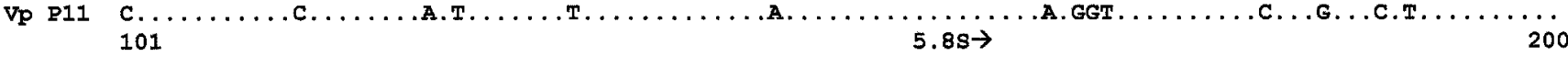

Vi 302 GAATTAGCCAACCCTGCCTGGAAAATTGAAGTCTGAGAACAAGTTAAATAAAACAAAACTTTCAACAACGGATCTCTTGGTTCTGGCAACGATGAAGAAC

Vi 1066

Sp 186

Sp 38.7

Se 1389

Vn P63

Vn $\mathrm{P} 17$

VP P64

$V_{P} p 11$

Vi 302

(a)

$\begin{array}{ll}\text { Vi } & 1066 \\ \text { Sp } & 186 \\ \text { Sp } & 38.7 \\ \text { Se } & 1389\end{array}$

Vn P63

Vn 217

Vp P64

Vp P11

Vi 302

Vi 1066

Sp 186

Sp 38.7

Se 1389

Vn $P 63$

Vn $P 17$

Vp P64

VP P11

Vi 302

Vi 1066

Sp 186

sp 38.7

Se 1389

Vn $\mathrm{P} 63$

Vn 117

Vp $P 64$

Vp P11 (1)

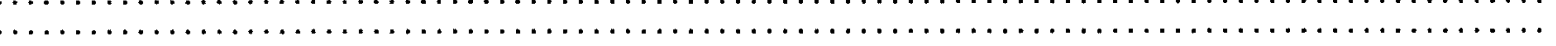

$\ldots \ldots \ldots \ldots \ldots \ldots \ldots \ldots \ldots \ldots \ldots \ldots \ldots \ldots \ldots \ldots \ldots \ldots \ldots \ldots \ldots \ldots \ldots \ldots \ldots \ldots \ldots \ldots \ldots \ldots \ldots \ldots \ldots \ldots \ldots \ldots \ldots \ldots \ldots \ldots \ldots \ldots \ldots \ldots$

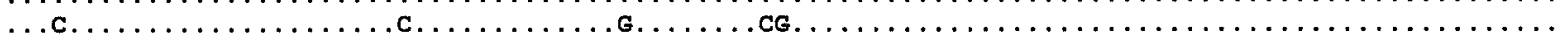

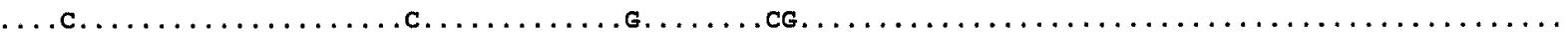

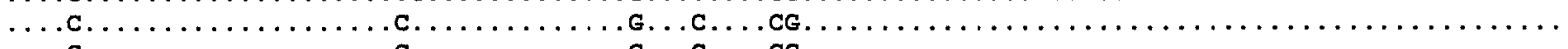

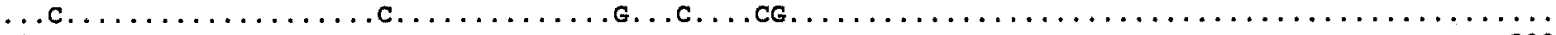
GCAGCGAAATGCGATAAGTAATGTGAATTGCAGATTCAGTGAATCATCGAATCTTTGAACGCACATTGCGCCCCCTGGTATTCCGGGGGGCACACCTGT

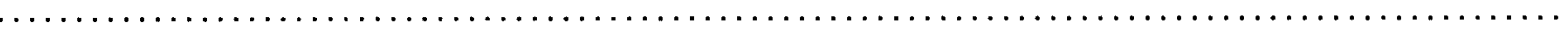

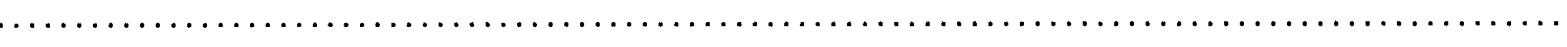

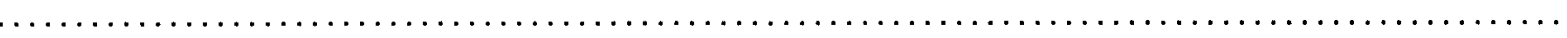

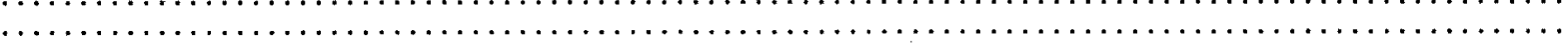

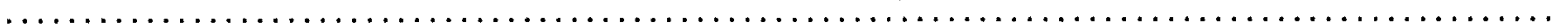

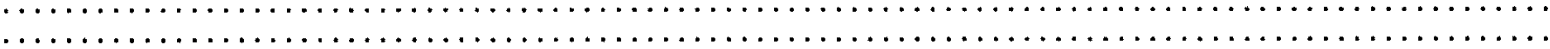

$301 \quad$ ITS2 $\rightarrow \quad 400$

TCGAGCGCCATTTCTACCCTGGAGCCCTGCTCTGTGATGGGCCCCGTCCTCGCGGACGGGCCCGAAACCCGTGGGCGCCGTCGTCCGGCCCTGAGCGTAG

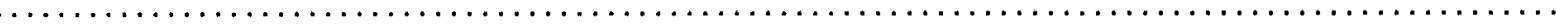

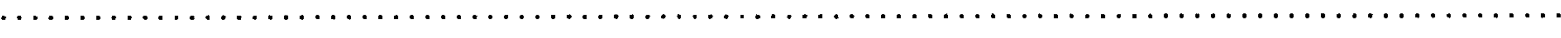

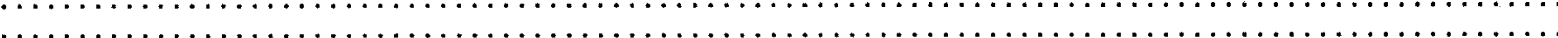

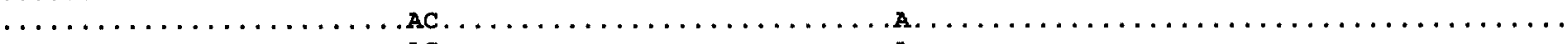

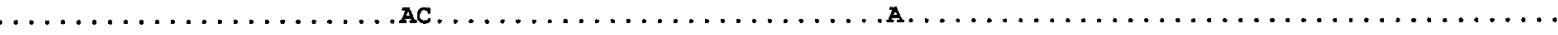

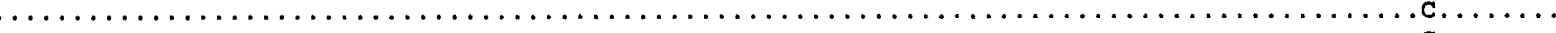

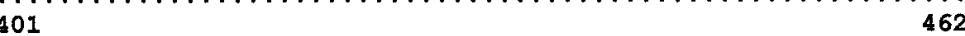

CAAGAGAATCCCTCGCTCGGAGTGTCTGTCGGCAGGCCGCCCCGAAACCCATATTTACAAG

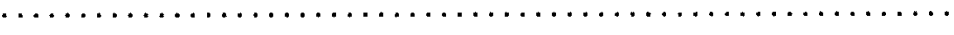

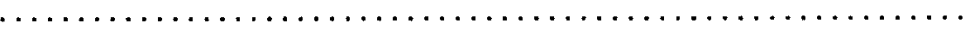

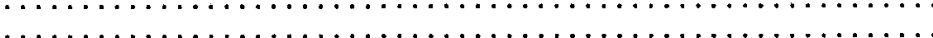

$\ldots \ldots \ldots \ldots \ldots \ldots \ldots \ldots$. . . . . . . . . . . . . . . . . . . .

$\ldots \ldots \ldots \ldots \ldots \ldots \ldots \ldots \ldots$. . . . . . . . . . . . . . . . . . . .

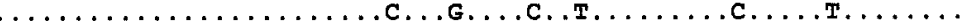

$\ldots \ldots \ldots \ldots \ldots \ldots \ldots \ldots$. . . . . . . . . . . . . . . . . . . .

Fig. 1. Alignment of the complete internal transcribed spacer (ITS) region ITS1-5.8S to ITS2 sequences of Venturia inaequalis (Vi) strains 302 and 1066; Spilocaea pyracanthae (Sp) strains 186 and 38.7; S. eriobotryae (Se) strain 1389; V. nashicola (Vn) strains P63 and P17; and V. pirina (Vp) strains P64 and P11; - indicates a nucleotide deletion. 
'Melrose') were used for the pathogenicity tests. The protocol for seed production, stratification, and seedling growth in the greenhouse was described previously (2). Concerning tests on Pyracantha spp., six clones were analyzed: 'Golden Charmer' ( $P$. coccinea $\times P$. rogersiana), 'Mohave' (Pyracantha $\times)$, 'Mozart' ( $P$. atalantioides), 'Saphyr Rouge' (Pyracantha $\times)$, 'Sunshine' $(P$. coccinea), and 'Watereri' (Pyracantha $\times)$. The pyracantha clones were cultivated in a greenhouse in the same conditions as apple seedlings.

Inoculation and grading. The inoculation tests were carried out threefold. The batches of apple seedlings were inoculated and incubated in a growth chamber according to the technique previously described (2). For each experiment, 146 to 219 apple seedlings of each cross were inoculated with each putative species. The plantlets of pyracantha were inoculated in the greenhouse for two experiments and in a growth chamber for the third. For each clone and experiment, 12 plantlets (2-month-old) produced from cuttings were tested with $V$. inaequalis and $S$. pyracanthae. Scab occurrence on seedlings was assessed after 11 days of incubation using the scale of Chevalier et al. (7). Symptoms were classified into six classes: seedlings in classes 0 to 3 a were considered as resistant and seedlings in classes $3 \mathrm{~b}$ and 4 as susceptible. The incidence of scab on pyracantha (percentage of scabbed plantlets) was scored after 22 to 26 days of incubation. For apple seedlings, the results are expressed as the percentage mean of scab-infected seedlings in each class. Concerning pyracantha, the percentage is calculated taking into account the three replications of the test. Strains 302 and 186 used in the mating experiment were tested further on a single experiment on 146 seedlings from the cross 'Golden Delicious' $\times$ 'Idared' following the same protocol.

Sequence analysis. ITS sequences were aligned using ClustalW (29). Virtual enzymatic restriction and phylogenetic tree were performed with Seqweb Version 1.1 (Wisconsin Package Version 10) from GCG software.

\section{RESULTS}

Interspecific variation in the ITS1-5.8S to ITS2 region. All DNA samples were amplified with the ITS1/ITS4 primers, and a single band product was visualized by electrophoresis in an agarose gel. Sequencing of the entire length of the ITS region showed no length variation between isolates of $V$. inaequalis, $S$. pyracanthae, $V$. nashicola, and the strain isolated from loquat (461 bp; Fig. 1) while ITS size of V. pirina was 462. Alignment of the ITS1-5.8S to ITS2 sequences of the two strains of $V$. inaequalis (302 and 1066) revealed a total homology with the two sequenced strains of $S$. pyracanthae (186 and D38.7) and with the strain isolated from loquat (1389) (Fig. 1). Their nucleotide sequences showed more than $92.4 \%$ of similarity with $V$. nashicola and $V$. pirina. Tree fruit pathogens were divided into two groups: a first group composed of strains related to the anamorph Spilocaea and the second group of the anamorph Fusicladium (Fig. 2). The amplified products from 17 strains of $V$. inaequalis and 12 strains of $S$. pyracanthae were digested with EcoRI, Tsp509I, RsaI, MspI, and TaqI. Whatever the enzymes used, digestion obtained from DNAs of $V$. inaequalis and $S$. pyracanthae presented the same banding patterns as those obtained from DNA extracted from $S$. eriobotryae (data not shown). No polymorphism was revealed within $V$. inaequalis and $S$. pyracantae (Fig. 3). Number and size of visualized DNA fragments were in accordance with virtual restriction obtained from sequence data of each species using application Seqweb, version 1.1, from GCG software.

Mating of $\boldsymbol{V}$. inaequalis and $\boldsymbol{S}$. pyracanthae. Only the cross between strain 302 (V. inaequalis) and strain 186 (S. pyracanthae) was fertile. A total of 974 mature and large perithecia were produced on the 112 foliar disks inoculated with mycelia of these two strains. No fruiting body was observed on leaves of the other tested cross. Disks from apple leaves produced 6.6 times more perithecia than those from pyracantha leaves. From a few crushed perithecia, we isolated 96 sporulating monoascosporic strains originating from the two types of leaves, which confirms the success of the cross.

Pathogenicity of $V$. inaequalis and $S$. pyracanthae isolates on apple seedlings and firethorn clones. Apple seedlings. Progenies obtained from the cross 'Golden Delicious' $\times$ 'Idared' were all susceptible to $V$. inaequalis inoculum (Fig. 4A); the distribution into six classes of symptoms in the progeny 'Florina' $x$ 'Melrose' showed a resistance/susceptible ratio close to 1:1 (282 resistant individuals and 223 susceptible individuals), corresponding to the segregation of the $V f$ resistance gene carried by cv. Florina. Progenies from the two crosses inoculated with $S$. pyracanthae showed typical resistance reaction, lack of symptoms (class 0 ) to symptoms of chlorosis or necrosis without sporulation (class 2) (Fig. 4B). Strain 302 (V. inaequalis) exhibited a compatible reaction when inoculated on Malus $\times$ domestica seedlings, whereas inoculation with strain 186 (S. pyracanthae) did not lead to any symptoms (class 0 ).

Pyracantha clones. The six clones inoculated with $S$. pyracanthae were susceptible (Table 2). Strong variation of susceptibility was observed between clones in our controlled experimental conditions. Data obtained with $V$. inaequalis inoculation showed that all clones were resistant. However, a plant of cv. Saphir Rouge that scored in the third experiment presented slight sporulation.

\section{DISCUSSION}

Based on alignment of ITS1-5.8S to ITS2 region sequences, a perfect homology has been observed between $V$. inaequalis (strains 302 and 1066), and S. pyracanthae (strains 186 and D38.7). These sequence data have been confirmed on a larger set of isolates by screening nucleotide variation with five restriction enzymes that had previously permitted clear differentiation among other Venturia spp. (16). Although the set of $V$. inaequalis included isolates of race 1 to 7 from diverse geographic origins, no vari-

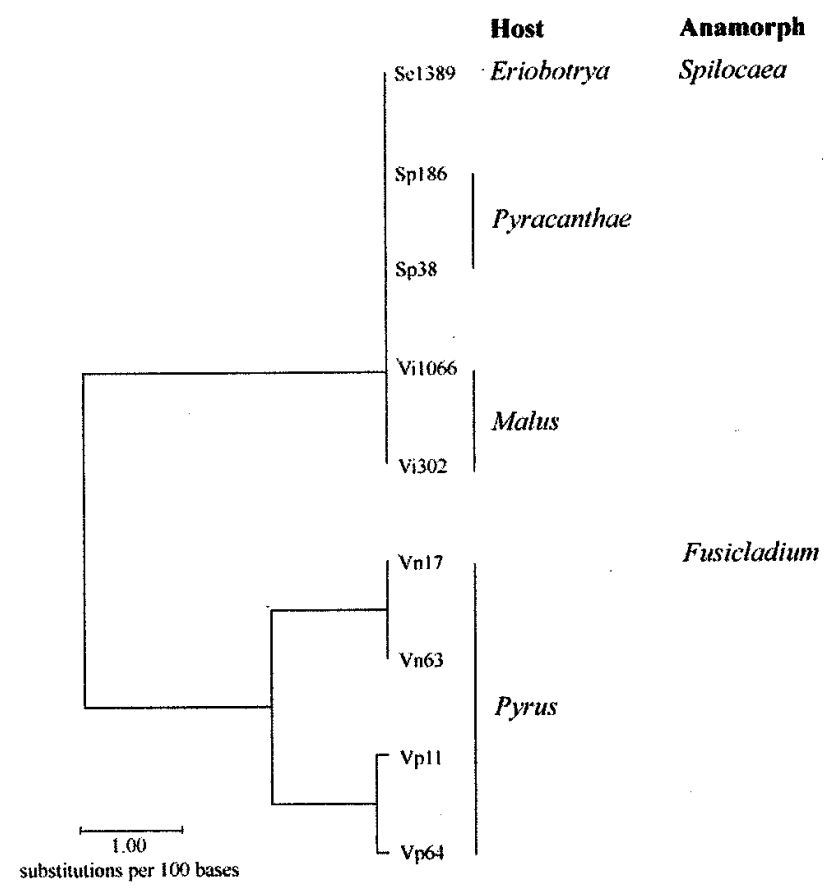

Fig. 2. Phylogram from analysis of the sequences of the internal transcribed spacer (ITS) ITS1-5.8S to ITS2 rDNA region of Venturia and Spilocaea spp. related to their anamorph and major host. The tree was constructed with the unweighted pair group method with arithmetic means method. Se: S. eriobotryae, Sp: S. pyracanthae, Vi: V. inaequalis, Vp: V. pirina, Vn: V. nashicola. Branches indicated numbers of substitutions per 100 bases. 
ation was detected. Within $V$. inaequalis, such a homology of nucleotide sequences of rDNA was expected regarding results obtained by Schnabel et al. (24), who reported slight variation that does not exceed $1.3 \%$. Within $S$. pyracanthae, no intraspecific variation was observed. Considering that many reports dealing with fungal species showed that intraspecific nucleotide variation of the total region of the ITS may exceed $10 \%$ (1), our results could be considered as self sufficient to propose that these two fungi belong to the same species.

One isolate of S. eriobotryae (Cav.) Hughes (1389) from loquat (Eriobotrya japonica) (Thunb.) Lindl. was included in the comparison. This isolate showed a sequence identical to strains of $V$. inaequalis and $S$. pyracanthae. According to Raabe and Gardner (21), loquat scab as well as firethorn scab are caused by $S$. pyracanthae which would have been recently introduced in the United States. Sequence data obtained in this study would tend to confirm their previous conclusion based on cross pathogenicity and morphology criteria. A perfect stage has never been reported on pyracantha; however, D'Oliviera and D'Oliviera reported immature perithecia in loquat leaves and, as a result, they named the fungus $V$. eriobotrya (Cav.) D'Oliviera (9). The two related species $V$. nashicola and $V$. pirina also were included in the study. Our results support previous reports (24) by demonstrating that these two fungi are closely related, but genetically distinct, from $V$. inaequalis and also from $S$. pyracanthae.

Mating tests were carried out to determine if fertility barriers existed between isolates from apple and firethorn. Using two parental strains of $V$. inaequalis with opposite mating types, we demonstrated that mating was possible with a strain isolated from pyracantha. High capacity for sporulation of ascospores produced both from apple and pyracantha leaves attested to the fertility of this cross. Keitt and Palmiter (15) demonstrated that V. inaequalis is a heterothallic fungus with two compatibility groups whose intragroup crosses are sterile. Our results clearly showed the capability of these two putative species to mate in vitro. These data confirmed our results in nucleotide sequencing, indicating that both entities represent the same species.

Cross-pathogenicity tests of $S$. pyracanthae and $V$. inaequalis strains on Pyracantha spp. and $M$. domestica demonstrated a host range specificity of each putative species. Typical sporulation le-

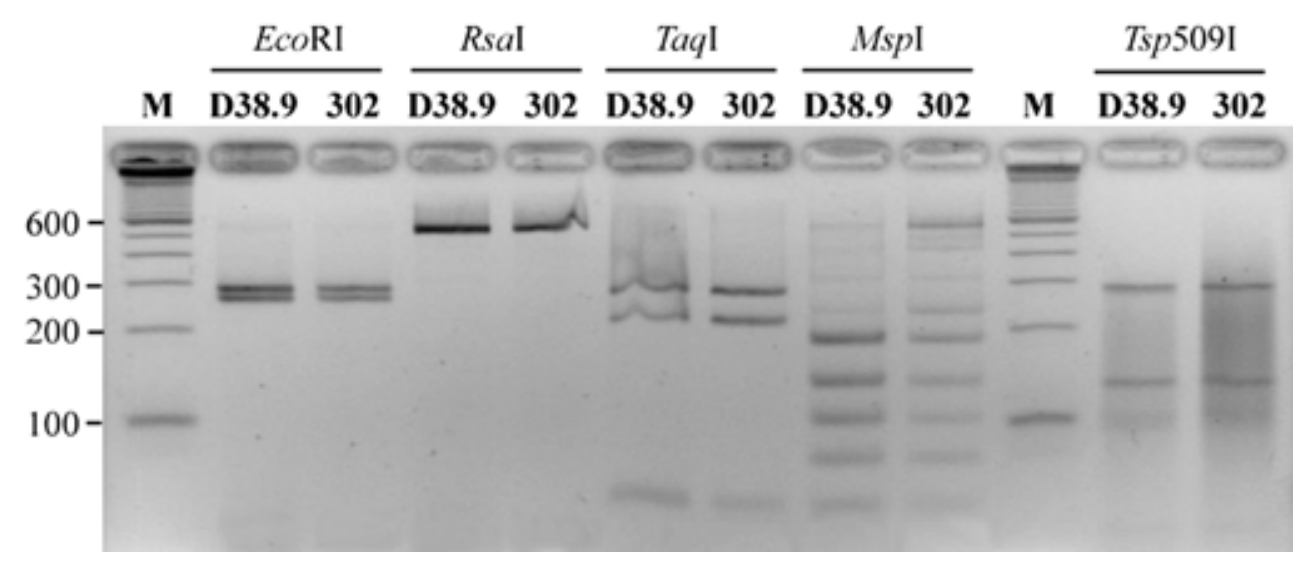

Fig. 3. Enzyme restriction digests of ribosomal DNA amplified from Venturia inaequalis (strain 302) and Spilocaea pyracanthae (strain D 38.9) with universal primers internal transcribed spacer 1 (ITS1) and ITS4 using EcoRI, RsaI, TaqI, MspI, and Tsp509I. Lane M, 100-bp ladder.

A

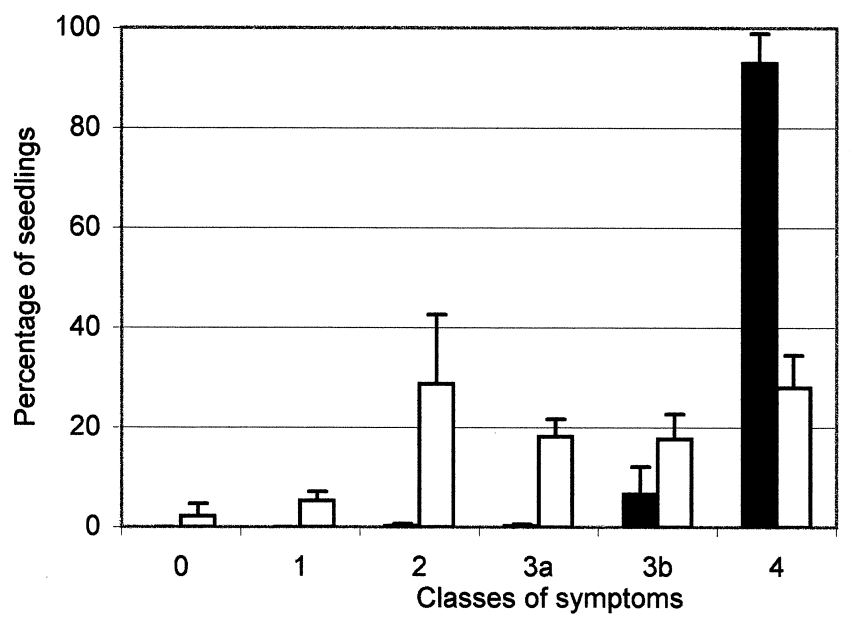

Resistant

Susceptible

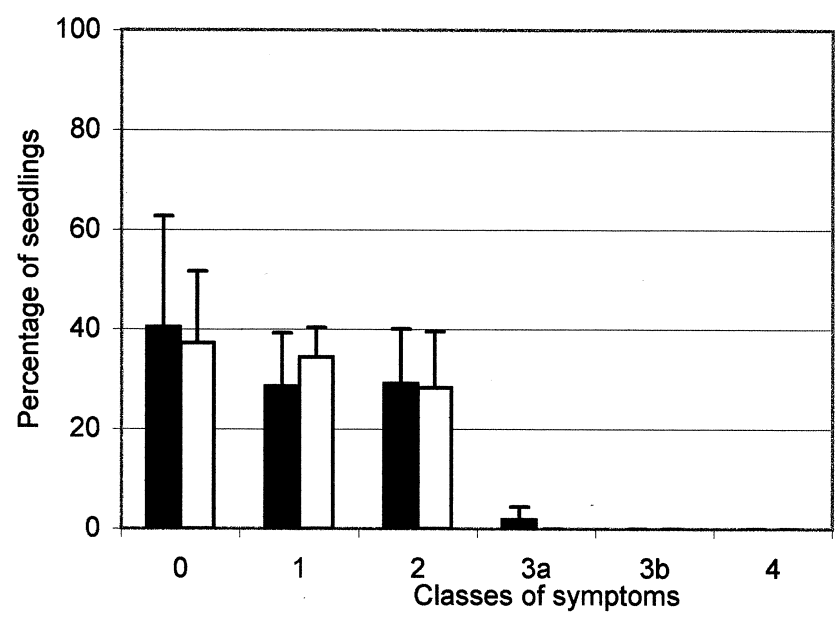

Resistant

Susceptible

Fig. 4. Distribution of two apple progenies originating from 'Golden delicious' $\times$ 'Idared' ( $\square)$ and 'Florina' $\times$ 'Melrose' ( $\square)$ into different classes of symptoms after inoculation with A, Venturia inaequalis and $\mathbf{B}$, Spilocaea pyracanthae. Symptoms were classified using the scale of Chevalier et al. $(7)$ : class $0=$ no symptom; class $1=$ hypersensitivity (pinpoint pits); class $2=$ resistance, chlorosis, either together or separate, without sporulation; class $3 \mathrm{a}=$ weak resistance, chlorosis, and necrosis, either together or separate, with slight sporulation; class $3 \mathrm{~b}=$ weak susceptibility, chlorosis, and necrosis, either together or separate, with sporulation; and class $4=$ susceptibility, abundant sporulation without chlorosis and necrosis, either together or separate. Results are the mean of three experiments; standard errors of the mean are indicated by bars. 
sions observed on pyracantha clones sprayed with inoculum of $S$. pyracanthae provided evidence of virulence of this inoculum. Analyzing distribution into the different classes of symptoms in the progenies 'Golden Delicious' $x$ 'Idared' and 'Florina' $x$ 'Melrose' clearly indicated a resistance reaction. Concerning $V$. inaequalis inoculations, all progeny of the cross 'Golden Delicious' $\times$ 'Idared' showed severe symptoms characteristic of a compatible reaction; $44.2 \%$ of the progeny of the cross 'Florina' $\times$ 'Melrose' did not: Florina contains the $V f$ gene (17) and fungal inoculum used carried the avirulence $a v r V f$; incompatible reaction occurred in the progeny with a segregation resistance/susceptible close to $1: 1$. In our experimental conditions, all tested firethorn clones were classified as resistant to $V$. inaequalis. Slight scab lesions were observed on the clone 'Saphir Rouge'; however, it was seen on a single plant tested in a growth chamber where conditions for disease development were optimal. Moreover, symptoms observed on this plant presented only slight sporulation scored as a $3 \mathrm{a}$ class on the scale of Chevalier (7). This class was created to score resistant plants carrying the $V f$ gene that expressed a slight sporulation in an incompatible reaction $(7,11)$, as observed with 'Prima' (14). Consequently, the phenotype observed on this plant was then considered resistant.

Thus, we demonstrated that $V$. inaequalis and $S$. pyracanthae were able to mate successfully and that pathogenicity tests carried out on a range of cultivars indicated occurrence of a host-specific response. We conclude that they are not sibling species as defined by Brasier and Rayner (4) because they are not distant enough genetically to have lost their capacity to cross. The three analyzed criteria (ITS nucleotide sequences, mating, and cross-pathogenicity) strongly suggest that these fungi are in a process of isolation due to host specialization that fits the definition of a "special form" (forma specialis). Suitable conditions for successful mating have been created in the laboratory on apple and firethorn leaves, suggesting that the thermostable component that stimulated pseudothecial development is also present in pyracantha leaves. The teleomorph of $S$. pyracanthae has never been seen in the field; therefore, we do not know whether such an event may occur between these two formae speciales. However, firethorn is an evergreen plant, so the need for a perfect stage in $S$. pyracanthae is probably not essential in its life cycle (21). Moreover, according to our results, isolates from pyracantha were not able to develop lesions on apple seedlings tested. These two facts reduced considerably the probabilities for these two formae speciales to mate in natural conditions. DNA fingerprinting using microsatellites developed for $V$. inaequalis (27) is underway in the laboratory to characterize the structure of these two populations and, thus, to look for occurrence of effective crossings in natural conditions.

Schnabel et al. (24) suggested that coevolution could explain the classification of Venturia spp.; the common ancestor of Venturia might have infected the common ancestor of the family Rosaceae. Host-specific differentiation in the anther smut fungus Microbotryum violaceum revealed by microsatellites clearly demonstrated that fungi from more distantly related host species are themselves more divergent (5). In our study, strains from fire-

TABLE 2. Incidence of the scab disease after inoculation of Spilocaea pyracanthae and Venturia inaequalis on six clones of Pyracantha spp. ${ }^{\mathrm{a}}$

\begin{tabular}{lcc}
\hline Pyracantha spp. clones & S. pyracanthae & V. inaequalis \\
\hline 'Golden Charmer' & 8.3 & 0 \\
'Watereri' & 13.8 & 0 \\
'Mozart' & 14.3 & 0 \\
'Saphyr Rouge' & 18.2 & 3.5 \\
'Mohave' & 33.3 & 0 \\
'Sunshine' & 61 & 0 \\
\hline
\end{tabular}

${ }^{a}$ Results, expressed in percentage of scabbed plantlets, are obtained from the whole inoculated plants of the three replicates. thorn and loquat are more closely linked to strains isolated from apple than from other tree-fruit hosts. Regarding distant taxonomic position of these two ornamental plants to Malus spp. and Pyrus spp. (6,23), coevolution cannot explain the phylogenic proximity of $V$. inaequalis, S. pyracanthae, and S. eriobotryae. Apple trees and firethorns have a common Asian origin, except the species $P$. coccinea, which would have originated from European countries around the Mediterranean to Caucase (3). Whether $V$. inaequalis was introduced in Europe with its host 2,000 to 2,500 years ago by the Greeks and Romans (18), no data are reported concerning geographical origin and historical spreading of $S$. pyracanthae. Therefore, further genetic diversity comparison of populations from Europe and Asia would permit a conclusion to be made regarding these two aspects.

Results obtained in this study allowed us to conclude that pyracantha does not act as a source of diversity within populations of $V$. inaequalis and thus does not provide strains with new patterns of pathogenicity in apple orchards both in terms of virulence and aggressiveness. However, sexual mating is possible in the laboratory; therefore, the genetic basis of host specificity would be worth investigating within the genus Venturia. The 96 progenies obtained in this study will permit the elucidation of genetic determinants of pathogenicity of these two pathogens. On the basis of the results of this study, we propose that Venturia isolates from Malus $\times$ domestica and from Pyracantha spp. be considered as two distinct special forms respectively named as $V$. inaequalis $\mathrm{f}$. sp. pomi and V. inaequalis f. sp. pyracanthae.

\section{ACKNOWLEDGMENTS}

We thank A. Kollar and J. L. Notteghem for providing fungal isolates, M. Devaux and J. Gaudin for their helpful technical assistance, and J. P. Paulin for critical reading of the manuscript.

\section{LITERATURE CITED}

1. Arenal, F., Platas, G., Monte, E., and Pelaez, F. 2000. ITS sequencing support for Epicoccum nigrum and Phoma epicoccina being the same biological species. Mycol. Res. 104:301-303.

2. Bénaouf, G., and Parisi, L. 2000. Genetics of host-pathogen relationships between Venturia inaequalis races 6 and 7 and Malus species. Phytopathology 90:236-242.

3. Bertrand, H., Cadic, A., and Belin, J. 1992. Pyracantha. PHM Revue Horticole, Paris.

4. Brasier, C. M., and Rayner, A. D. M. 1987. Whither terminology below the species level in the fungi. Pages 379-388 in: Evolutionary Biology of the Fungi. A. D. M. Rayner, C. M. Brasier, and D. Moore, eds. Cambridge University Press, Cambridge.

5. Bucheli, E., Gautschi, B., and Shykoff, J. A. 2000. Host-specific differentiation in the anther smut fungus Microbotryum violaceum as revealed by microsatellites. J. Evol. Biol. 13:188-198.

6. Campbell, C. S., Donoghue, M. J., Baldwin, B. G., and Wojciechowski, M. F. 1995. Phylogenetic relationships in Maloideae (Rosaceae): Evidence from sequences of the internal transcribed spacers of nuclear ribosomal DNA and its congruence with morphology. Am. J. Bot. 82:903918.

7. Chevalier, M., Lespinasse, Y., and Renaudin, S. 1991. A microscopic study of different classes of symptoms coded by the gene $V f$ in apple for resistance to scab (Venturia inaequalis). Plant Pathol. 40:249-256.

8. Crosby, J. A., Janick, J., Pecknold, P. C., Korban, S. S., O'Connor, P. A., Ries, S. M., Goffreda, J., and Voordeckers, A. 1992. Breeding apples for scab resistance: 1945-1990. Fruit Var. J. 46:145-166.

9. D’Oliviera, B., and D'Oliviera, M. 1946. Nota sôbre os corpos M do tricoginio e do anteridio nas Venturia ineaqualis, $V$ pirina, e $V$. eriobotryae. Agron. Lusit. 8:291-301.

10. Egolf, D. R. 1970. Pyracantha 'Mohave'. A new cultivar (Rosaceae). Baileya 17:79-82.

11. Gardiner, S. E., Basset, H. C. M., Noiton, D. A. M., Bus, V. G., Hofstee, M. E., White, A. G., Ball, R. D., Forster, R. L. S., and Rikkerink, E. H. A. 1996. A detailed linkage map around an apple scab resistance gene demonstrate that two disease resistance classes both carry the $V f$ gene. Theor. Appl. Genet. 93:485-493.

12. Goodwin, D. C., and Lee, S. B. 1993. Microwave miniprep of total genomic DNA from fungi, plants, protists and animals for PCR. Bio- 
techniques 15:438-444.

13. Hernàndez Castillo, F. D., Parisi, L., and Lespinasse, Y. 1994. Heredabilidad del factor de avirulencia de una cepa de Venturia inaequalis (Cke.) Wint. Sobre el cultivar de manzano (Malus $\times$ domestica Borkh.) Golden Delicious. Rev. Mex. Fitopatol. 12:31-34.

14. Hough, L. F., Williams, E. B., Dayton, D. F., Shay, J. R., Bailey, C. H., Mowry, J. B., Janick, J., and Emerson, F. H. 1970. Progress and problems in breeding apples for scab resistance. Pages 217-230 in: Proc. Eucarpia Fruit Sect. Symp. Tree Fruit Breeding, Angers. Institut National de la Recherche Agronomique, Versailles.

15. Keitt, G. W., and Palmiter, D. H. 1938. Heterothallism and variability in Venturia inaequalis. Am. J. Bot. 25:338-345.

16. Le Cam, B., Devaux, M., and Parisi, L. 2001. Specific polymerase chain reaction identification of Venturia nashicola using internally transcribed spacer region in the ribosomal DNA. Phytopathology 91:900-904.

17. Lespinasse, Y., Olivier, J. M., Lespinasse, J. M., and Le Lezec, M. 1985. Florina Querina la résistance du pommier à la tavelure. Arboric. Fruit. 387:43-47.

18. MacHardy, W. E. 1996. Apple Scab. Biology, Epidemiology, and Management. The American Phytopathological Society, St. Paul, MN

19. Parisi L., Durel, C. E., and Laurens, F. 2000. First report on the presence of Venturia inaequalis race 7 in French apple orchard. Pages 99-104 in: Integrated Control of Pome Fruit Diseases, Vol. XXIII (12). L. Parisi, ed. IOBC/WPRS, Gent, Belgium.

20. Parisi, L., Lespinasse, Y., Guillaumes, J., and Krüger, J. 1993. A new race of Venturia inaequalis virulent to apples with resistance due to the gene $V f$. Phytopathology 83:533-537.

21. Raabe, R. D., and Gardner, M. W. 1972. Scab of Pyracantha, Loquat, Toyon, and Kageneckia. Phytopathology 62:914-916.

22. Roberts, A. L., and Crute, I. R. 1994. Apple scab resistance from Malus floribunda $821(V f)$ is rendered ineffective by isolates of Venturia inaequalis from Malus floribunda. Norw. J. Agric. Sci. Suppl. 17:403-406.

23. Robertson, K. R., Rohrer, J. R., Phipps, J. B., and Smith, P. G. 1987. Generic delimitation in subfamily Maloïdeae (Rosaceae). 14th Int. Botanical Congr., Berlin.

24. Schnabel, G., Schnabel, E. L., and Jones, A. L. 1999. Characterization of ribosomal DNA from Venturia inaequalis and its phylogenetic relationship to rDNA from other tree-fruit Venturia species. Phytopathology 89:100-108.

25. Sherriff, C., Whelan, M. J., Arnold, G. M., Lafay, J.-F., Brygoo, Y., and Bailey, J. A. 1994. Ribosomal DNA sequence analysis reveals new species groupings in the genus Colletotrichum. Exp. Mycol. 18:121-138.

26. Sivanesan, A. 1977. The Taxonomy and Pathology of Venturia Species. J. Cramer, Vaduz, Liechenstein.

27. Tenzer, I., degli Ivanissevich, S., Morgante, M., and Gessler, C. 1999. Identification of microsatellite markers and their application to population genetics of Venturia inaequalis. Phytopathology 89:748-753.

28. Tenzer, I., and Gessler, C. 1999. Genetic diversity of Venturia inaequalis across Europe. Eur. J. Plant. Pathol. 105:54-552.

29. Thompson, J. D., Higgins, D. G., and Gibson, T. J. 1994. CLUSTAL W: Improving the sensitivity of progressive multiple sequence alignment through sequence weighting, positions-specific gap penalties and weight matrix choice. Nucleic Acids Res. 22:4673-4680.

30. White, T. J., Bruns, T., Lee, S., and Taylor, J. 1990. Amplification and direct sequencing of fungal ribosomal RNA genes for phylogenetics. Pages 315-322 in: PCR Protocols, A Guide to Methods and Applications. M. A. Innis, D. H. Gelfand, J. J. Sninsky, and T. J. White, eds. Academic Press, San Diego, CA.

31. Williams, E. B., and Brown, A. G. 1968. A new physiological race of Venturia inaequalis, incitant of apple scab. Plant Dis. Rep. 52:799-801. 